\title{
The influence of teachers' professional competency and working discipline on teachers' performance at state elementary school
}

\author{
Selamat Biora ${ }^{1}$, Yasir Arafat ${ }^{2}$, Mulyadi Mulyadi $^{2}$ \\ ${ }^{1}$ Sekolah Dasar Negeri 10 Banyuasin I, Indonesia \\ ${ }^{2}$ Universitas PGRI Palembang, Indonesia
}

\section{Article Info}

\section{Article history:}

Received Jul 12 $2^{\text {th }}, 2021$

Revised Aug $20^{\text {th }}, 2021$

Accepted Aug 26 $6^{\text {th }}, 2021$

\section{Keyword:}

Discipline

Professional competence

Performance

\begin{abstract}
This study aimed to know and analyze: (1) the influence of professional competence on teachers' performance; (2) the influence of work discipline on teachers' performance; and (3) the influence of professional competence and work discipline simultaneously on teachers' performance. The data in this study were collected through questionnaires and analyzed by using multiple regression analysis through the $t$ test, $F$ test, and determination coefficient test. The population in this study were all junior high school teachers in Banyuasin I district, Banyuasin Regency, totaling 323 people. The sampling technique in this study was probability sampling using the Slovin formula to obtain 76 teachers as the research sample. The results of the study found that: (1) there was a significant influence between professional competence and teachers' performance; (2) there was a significant influence between work discipline on teachers' performance; (3) there was a significant influence between professional competence and work discipline simultaneously on teachers' performance.
\end{abstract}

C 2021 The Authors. Published by IICET

This is an open access article under the CC BY-NC-SA license (https://creativecommons.org/licenses/by-nc-sa/4.0

\section{Corresponding Author:}

Biora, S.,

Sekolah Dasar Negeri 10 Banyuasin I, Indonesia

Email: biora1cat@gmail.com

\section{Introduction}

National education has the aim of developing the potential of students to become human beings who believe and fear God Almighty (RI Law Number 20 of 2003 on National Education System Article 3). In Permen PAN and RB Number 16 of 2009 Article 1 it is explained that teachers are professional educators with the main task of educating, teaching, guiding, directing, training, assessing, and evaluating students in early childhood education through formal education, basic education, and education. medium. Based on this explanation, the teacher is one of the parties who has the responsibility to develop abilities and shape the character of students so that they are in accordance with the demands of the National Education System and can produce superior students and schools. Teachers, both individually and in groups, are expected with their teaching abilities to change a condition of learning to be of higher quality.

Teachers have many roles, not only as teachers who transfer of knowledge, but also as guides who encourage potential, develop alternatives, and mobilize students in learning. This means that teachers have complex duties and responsibilities towards achieving educational goals, where teachers are not only required to master the knowledge to be taught and have a set of teaching knowledge and technical skills, but teachers are also required to display a personality that is capable of being role models for students. For this reason, [1] human resources must be improved, especially teachers by paying attention to their very large duties, roles, 
and responsibilities, teachers must be given support or motivation so that their competencies can be implemented optimally through good performance

Republic of Indonesia Law No. 14 of 2005 concerning Teachers and Lecturers stated that teachers are professional educators with the main task of educating, teaching, guiding, directing, training, assessing, and evaluating students in early childhood educators, primary and secondary educators. In Law No. 14 of 2005 , it is explained that teachers have a position as professional staff at the levels of early childhood education, basic education and secondary education, in the formal education pathway which is appointed in accordance with statutory regulations (Article 2 of RI Law No. : 2005). It is further stated that teachers are required to have academic qualifications, competencies, teacher certificates, as well as physical and spiritual, and have the competence to realize the goals of national education

Competencies that must be possessed by professional teachers are pedagogical competence, personality competence, social competence, and professional competence. In this case, professional competence is one of the competencies that teachers must have in the learning process. Professional competence is the teacher's ability to master the fields of science, technology, and cultural arts that will have an impact on the resulting performance.

[2] Productivity is determined by employee performance and technology, while employee performance itself depends on two things, namely ability and motivation. Meanwhile, [3] Argues that the factors that influence performance are: a. Individual variables which include abilities, skills, mental and physical, family background, social level, experience (age, origin, gender). b. Organizational variables which include resources, leadership, reward (compensation), job design structure. c. Psychological variables which include perceptions, attitudes, personality, learning and motivation. Based on the expert opinion above, it appears that many factors affect performance and one of them is competence.

The competence or ability of a teacher is a very important pillar in determining whether or not a teacher's professional performance is good. Teachers have an important role in learning, because teachers have direct involvement with students in the teaching and learning process. The teacher must create a conducive atmosphere so that students are willing to be fully involved in learning activities, so that the learning objectives that have been set can be achieved effectively and efficiently. Regarding teacher competence in relation to teaching activities, [4] the learning process carried out by the teacher and student learning outcomes are not only determined by the school, pattern, structure, and curriculum content, but are largely determined by competence. teacher.

Teachers who have professional competence can select content, plan lessons, organize appropriate materials and assignments in various ways to make learning effective. To make this learning effective, a teacher must plan carefully starting from making lesson plans, delivering material, selecting methods, and several things that are needed in the learning process. The plan is prepared so that what is conveyed can be achieved as expected. Teacher professional competence is needed in order to develop the effectiveness of learning, because with professional competence teachers can manage the time that has been provided.

This is supported by the results of research conducted by [5] which proves previous theory and research, that true performance is the result of sincere work, smart work, hard work, and thorough work, and competence is a requirement. The teaching profession is one of the jobs that demands complexity of abilities, both physical, mental and material. And the true teacher's performance is to educate the nation's life. Through capacity building, it is hoped that quality education can be delivered (performance), and with that it can produce a generation that is religious, intelligent, independent, has character and competitiveness.

[6] Through their research also found that increasing teacher professional competence can have an impact on improving teacher performance, as research results show that teacher professional competence has a positive and significant effect on teacher performance. That is, there is a direct effect between professional competence and teacher performance, where when professional competence increases, teacher performance will also increase and vice versa when professional competence decreases, teacher performance will also decrease [7].

Another factor that can have an influence on performance is work discipline. Work discipline is one of the factors that affect performance. [8] discipline is the awareness and willingness of a person to obey all company regulations and applicable social norms. Thus discipline is an attitude to comply with and obey all organizational rules in doing work to achieve the expected goals. Discipline is related to the existence of rules or regulations. So that a disciplined teacher can be interpreted as a teacher who obeys all the rules that have been established by the organization and applicable social norms. 
Good discipline reflects a person's sense of responsibility for the tasks assigned to him. With discipline, it can encourage work passion, morale, and support the realization of planned goals. High discipline will be able to build professional performance, because a good understanding of the discipline of the teacher is able to observe the rules and strategic steps in carrying out the teaching and learning process. Discipline for teachers is an integral part in carrying out their duties and obligations.

This is in line with the results of research by [9] simultaneous effect of work discipline, work motivation, and school principal supervision on teacher performance by $65.4 \%$. Meanwhile, the partial effect of work discipline is $17.56 \%$ on teacher performance. With work discipline, it can improve teacher performance.

[10] through his research also proves that there is a partial influence between work discipline on teacher performance by $47.47 \%$. Likewise, research by [11], [12], [13] also shows that work discipline has a positive and significant effect on teacher performance.

This research was conducted to Stateelementary school teachers ofBanyuasin I district. The results of the pre-research interview that the writer conducted with one of the SD Negeri teacherofBanyuasin I district showed that the level of teacher performance was still low and meant that the management of the teaching and learning process, teacher self-development and teaching competence was needed to be improved. Coaching and supervision of teachers must be carried out continuously. Another problem from the results of preliminary observations / observations conducted by writer in several public elementary schools of Banyuasin I District was that in terms of teaching and learning, the professional competence of some teachers was good enough. A professional teacher in learning is a teacher who masters the material being taught, is able to develop the material creatively, uses a variety of learning methods. However, there were some teachers who were less professional, which could be seen from: lack of mastery of teaching materials, teachers still lookat at textbooks while teaching, only explained material in one place without moving, did not use props or learning media that can attract students' interest. So that student motivation to learn decreased, the teacher did not involve students when learning. In terms of work discipline, there were still teachers who were often late to class and sometimes didn't come without clear reasons. Low competence and work discipline would certainly affect the teacher's performance.

Based on these descriptions, the writer was interested in conducting further research on "The Effect of Teacher Professional Competence and Work Discipline on the Performance of State Elementary School Teachers ofBanyuasin I District".

\section{Method}

This research was a correlational research, which was a research conducted by researchers to determine the level of the relationship between two or more variables, without making changes, additions or manipulations to existing data (Arikunto, 2010: 4). In this study, professional competence and work discipline as independent variables would be tested for their effect on teachers' performance as the dependent variable.

The population in this study were all teachers teaching at SD NegeriBanyuasin I Subdistrict, Mariana and Merah Mata, totaling 323 people, consisting of 30state primary schools. The sampling technique used probability sampling technique. Sugiyono (2012: 164) explained that probability sampling is a sampling technique that provides equal opportunities for each element (member) of the population to be selected as a sample member. The determination of the number of samples was done by means of calculations by using the Slovin formula. The formula was used to determine the sample size at a rate of $10 \%$.

The Slovin formula used was as follows:

$n=\frac{N}{1+N e^{2}}$

Where

$\mathrm{n}=$ sample size

$\mathrm{N}=$ population size

$\mathrm{e}=$ error that can be tolerated 10\% (Umar, 2005: 78).

Based on the Slovin formula, the amount of the research sample draw is:

$n=\frac{323}{1+323 \cdot 0.1^{2}}$

$n=\frac{323}{1+3,23}$ 


$$
\begin{aligned}
& n=\frac{323}{4,23} \\
& n=76 \\
& n=76
\end{aligned}
$$

Based on the above calculations, the sample obtained was 76 respondents. The number of samples that had been obtained was then divided into 30 schools so that the determination of the number of samples in

\begin{tabular}{|c|c|c|c|c|}
\hline No & Name of School & Population & Sampling & Sample \\
\hline 1 & SDN 1 Banyuasin I & 14 & $14 / 323 * 76$ & 3 \\
\hline 2 & SDN 2 Banyuasin I & 9 & $9 / 323 * 76$ & 2 \\
\hline 3 & SDN 3 Banyuasin I & 8 & $8 / 323 * 76$ & 2 \\
\hline 4 & SDN 4 Banyuasin I & 13 & $13 / 323 * 76$ & 3 \\
\hline 5 & SDN 5 Banyuasin I & 8 & $8 / 323 * 76$ & 2 \\
\hline 6 & SDN 6 Banyuasin I & 11 & $11 / 323 * 76$ & 3 \\
\hline 7 & SDN 7 Banyuasin I & 16 & $16 / 323 * 76$ & 4 \\
\hline 8 & SDN 8 Banyuasin I & 8 & $8 / 323 * 76$ & 2 \\
\hline 9 & SDN 9 Banyuasin I & 11 & $114 / 323^{*} 76$ & 3 \\
\hline 10 & SDN 10 Banyuasin I & 23 & $23 / 323^{*} 76$ & 5 \\
\hline 11 & SDN 11 Banyuasin I & 10 & $10 / 323 * 76$ & 2 \\
\hline 12 & SDN 12 Banyuasin I & 9 & $9 / 323 * 76$ & 2 \\
\hline 13 & SDN 13 Banyuasin I & 10 & $10 / 323 * 76$ & 2 \\
\hline 14 & SDN 14 Banyuasin I & 11 & $11 / 323 * 76$ & 3 \\
\hline 15 & SDN 15 Banyuasin I & 9 & $9 / 323 * 76$ & 2 \\
\hline 16 & SDN 16 Banyuasin I & 9 & $9 / 323 * 76$ & 2 \\
\hline 17 & SDN 17 Banyuasin I & 9 & $9 / 323^{*} 76$ & 2 \\
\hline 18 & SDN 18 Banyuasin I & 15 & $15 / 323 * 76$ & 4 \\
\hline 19 & SDN 19 Banyuasin I & 16 & $16 / 323 * 76$ & 4 \\
\hline 20 & SDN 20 Banyuasin I & 15 & $15 / 323 * 76$ & 4 \\
\hline 21 & SDN 21 Banyuasin I & 9 & $9 / 323 * 76$ & 2 \\
\hline 22 & SDN 22 Banyuasin I & 8 & $8 / 323 * 76$ & 2 \\
\hline 23 & SDN 23 Banyuasin I & 10 & $10 / 323 * 76$ & 2 \\
\hline 24 & SDN 24 Banyuasin I & 8 & $8 / 323 * 76$ & 2 \\
\hline 25 & SDN 25 Banyuasin I & 9 & $9 / 323 * 76$ & 2 \\
\hline 26 & SDN 26 Banyuasin I & 8 & $8 / 323^{*} 76$ & 2 \\
\hline 27 & SDN 27 Banyuasin I & 10 & $10 / 323 * 76$ & 2 \\
\hline 28 & SDN 28 Banyuasin I & 9 & $9 / 323 * 76$ & 2 \\
\hline 29 & SDN 29 Banyuasin I & 9 & $9 / 323 * 76$ & 2 \\
\hline \multirow[t]{2}{*}{30} & SDN 30 Banyuasin I & 9 & $9 / 323 * 76$ & 2 \\
\hline & TOTAL & 323 & & 76 \\
\hline
\end{tabular}
each school had the same proportion.

Table $1<$ Sample of the Study $>$

After obtaining the desired number of samples, then sampling from each school was determined by using simple random technique (simple random sampling). In random sampling, all elements or elements in the population had the same opportunity to be selected as a sample representing the population. Samples were taken by lottery system and drawn according to the number of samples from the population at each school. 
Data collection techniques in this study were carried out through observation, documentation, and questionnaires. The data in this study were analyzedby using multiple regression analysis through the $t$ test, $F$ test, and determination coefficient test..

\section{Results and Discussions}

\section{Normality Test}

Table $2<$ Normality Test Result $>$

\begin{tabular}{lccc}
\hline & \multicolumn{3}{c}{ Kolmogorov-Smirnov $^{\mathrm{a}}$} \\
\cline { 2 - 4 } & Statistic & $\mathrm{df}$ & Sig. \\
\hline Kinerja & .083 & 76 & $.200^{*}$ \\
Kompetensi & .097 & 76 & .076 \\
Disiplin & .100 & 76 & .057 \\
\hline
\end{tabular}

*. This is a lower bound of the true significance.

a. Lilliefors Significance Correction

Table 1 shows the Kolmogorov Smirnov-z value for the teacher performance variable was .083, the professional competency variable was 0.097 , and the work discipline variable was .100. Asymp Value. The variable of teacher performance was .200, the variable of professional competence was 0.076 , and the variable of work discipline was .057 , The sig values were greater than 0.05 , so it can be stated that the research variables used in this study had a normal distribution.

\section{Heteroscedasticity Test}

Heteroscedasticity test aims to test whether in regression there is an inequality of variance from the residuals of one observation to another. If the residual variance from one observation to another is constant, it is called Homoscedasticity and if it is different it is called Heteroscedasticity. To detect heteroscedasticity in this study was to look at the presence or absence of a certain pattern on the scatterplot graph between SRESID and ZPRED, where the Y axis was the predicted $\mathrm{Y}$ and the $\mathrm{X}$-axis was the studentized residual (Y-predicted $\mathrm{Y}$ ).

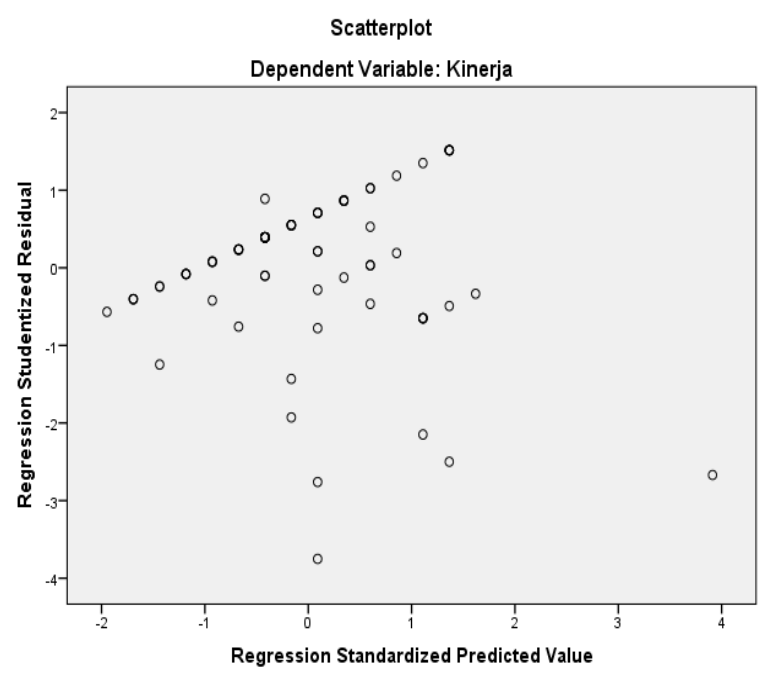

Figure $1<$ Heteroscedasticity Test Results $>$

Based on Figure 1, it can be seen that the distribution of data was around the zero point on the $\mathrm{Y}$ axis, and there was no certain pattern or trend line on the data distribution. This meant that there was no heteroscedasticity.

\section{Multicollinearity Test}

To determine the presence or absence of multicollinearity symptoms in the regression model, this study was carried out through a collinearity statistical test by looking at the Variance Inflation Factor (VIF) value and the Tolerance value. The test criteria with VIF, namely if the VIF value $>10$ There are symptoms of 
multicollinearity; Conversely, if the VIF value $<10$, there are no symptoms of multicollinearity. The multicollinearity test results can be seen in Table 2 .

Table $3<$ Multicollinearity Test Result $>$

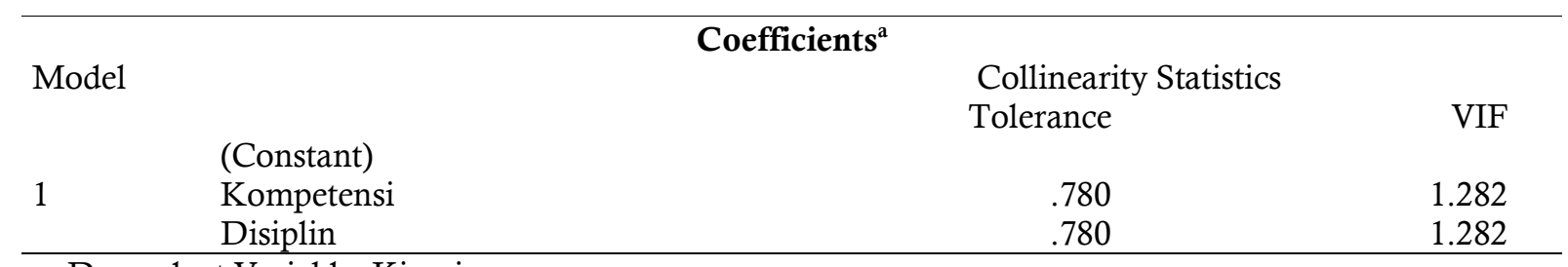

a. Dependent Variable: Kinerja

Based on Table 2, it was known that the VIF value of teachers' performance variables, professional competence and work discipline were less than 10 (VIF $<10$ ), so it can be concluded that the data tested had no symptoms of multicollinearity.

\section{Homogeneity Test Results}

The homogeneity test of the research data was carried out with Levene's test of homogeneity of variances statistics.

Table $4<$ Homogeneity Test Result $>$

\begin{tabular}{cccc}
\hline Levene Statistic & df1 & df2 & Sig. \\
.621 & 2 & 76 & .324 \\
\hline
\end{tabular}

The test criterion is the significance value $<0.05$, so the group variants are not the same. Conversely, if the significance level is $\geq 0.05$, the variance of the data group is the same. From the output of the table above, it can be seen that the significance value was $0.324>0.05$. so it can be concluded that the data were declared homogeneous.

\section{Linearity Test}

To find out whether the two variables had a linear or not significant relationship, the linearity test was used. Linearity test is a prerequisite in linear regression analysis. In this case, [18] the variable teacher professional competence has a linear or not relationship with the teacher performance variable and the teacher work discipline variable has a linear or not relationship with the teacher performance variable. Linearity is calculated to find out whether the regression line between $\mathrm{X}$ and $\mathrm{Y}$ forms a linear line or not. If it is not linear, the regression analysis cannot be continued (Sugiyono, 2012: 265).

It is called linearity because there is a linear relationship between variables, and every change that occurs in one variable will be followed by a change with a magnitude that is parallel to the other variables. The guideline used to determine the degree of linearity is to look at the results of the analysis of the SPSS application program with the Compare Means function on the line deviation from linearity, while to determine the meaning of the regression direction by considering the analysis results in the linearity line. If the value is sig. dev from Linearity is greater than 0.05 then the relationship between the independent variable and the dependent variable is linear, on the contrary, the relationship between the two variables is not linear, if the value is sig. dev. From linearity less than 0.05 . The linearity test of the independent variables and the dependent variable was carried out by means of a means options test for linearity in the SPSS program application with a significance level of $5 \%(\alpha=0.05)$.

Table $5<$ Linearity Test Results for X1 to Y Variables $>$

\begin{tabular}{lc}
\hline Correlation & Sig. Dev from Linearity \\
$\mathrm{X} 1$ to $\mathrm{Y}$ & 0.088 \\
$\mathrm{X} 2$ to $\mathrm{Y}$ & 0.731 \\
\hline
\end{tabular}

Based on the Anova Table above, the results of calculations through the SPSS version 21 application program above obtained a significant value of deviation from linearity for the professional competency variable, which was 0.088 more than 0.05 , meaning that it can be concluded that there was a linear relationship between professional competence variables. significantly with teacher performance. While, significant value of deviation from linearity for the work discipline variable was 0.731 more than 0.05 , meaning that there was a linear relationship between work discipline variables. significantly with teacher performance. 


\section{Hypothesis Testing Results}

1. The first hypothesis (Partial Hypothesis of Variable X1 to Y)

Ha: $\rho>0 ; \mathrm{H} 0: \rho=0$

H0: there was no positive and significant influence between professional competence on teachers' performance.

Ha: there was a positive and significant influence between professional competence on teachers' performance.

The t-test was carried out by comparing the sig. and coefficients with t-table value and probability level 0.05 . The basis for the decision making for the $t$ test is to compare the calculated statistical value with the table statistics. If the $\mathrm{t}$ statistic $\leq \mathrm{t}$ table statistic, then Ho is accepted and vice versa if the $\mathrm{t}$ statistic $>\mathrm{t}$ table statistic, then Ho is rejected. It was known that the $\mathrm{t}$-table was 1.99254 obtained from the $\mathrm{t}$ table with $\mathrm{df}=\mathrm{n}-\mathrm{k}=76-2(\mathrm{df}=76-2, \mathrm{df}=74)$ and alpha $0.05 . \mathrm{n}$ was the number of samples and $\mathrm{k}$ was the number of independent variables. With a two-sided test (significant $=0.025$ ) the results were obtained for the $t$ table of 2.0017. Based on the explanation above, namely tcount $=11.408$ and $t$-table $=1.99254$, then $\mathrm{t}$-count $\geq \mathrm{t}$-table which means that Ho was rejected and Ha was accepted or it was concluded that partially there was a positive and significant influence between professional competence on teachers' performance.

In this study, the results of the partial test ( $t$ test) of the variable professional competence on teachers' performance found that there was an effect of professional competence on teachers' performance and it could be said that individual professional competence variables had a significant effect on teacher performance with a sig value smaller than the probability and tcount values. greater than $\mathrm{t}$ table. It also shows that, if the demonstrated professional competence of the dimensions: pedagogic competence; personality competence; professional competence; and social competence increased, would be followed by an increase on teachers' performance and vice versa if professional competence decreased, would be followed by a significant decrease in teacher performance.

The writer also made observations on several research samples to support the research results. The results of the researcher's observations found that the professional competence of SD Negeri teachers in the Banyuasin I district was quite good as seen from the fulfillment of $73 \%$ of the observational indicators that the researcher used in this study. [14] Explains that teacher performance is a teacher's work performance in quality and quantity achieved by a teacher in carrying out the duties and responsibilities that have been assigned to him. Teacher competence is a teacher's ability that is formed from knowledge, skills, and attitudes or behavior. The formation of these 3 things is done through education and training. This study found that there was an effect of teacher competence on performance. This shows that one of the factors that influence teacher performance to achieve optimal performance is professional competence.

Professional competence is a competency that describes a special ability that is conscious and directed towards certain goals. As a profession, teachers should have professional competence. The ideal teacher is a teacher who has professional competence who is educated and trained, and has work experience in the field.

Teacher professional competence is an important factor for improving teacher performance. [15] "competency as rational performance which satisfactory meets the objectives for a desired condition". Competence is rational behavior to achieve the required goals in accordance with the expected conditions.

Problems that still often occur are related to professional competence in junior high schools which are the research samples, including some teachers who teach not according to their academic education. The economic level of teachers that is still low has an impact on teachers who wish to continue to higher levels of education. There are still teachers who have not carried out classroom action research so they do not know the deficiencies that occur in learning. Teachers tend to teach and educate students in moderation. Teachers are less able to teach in class because of their limitations in mastering the teaching methodology. The existence of problems related to this competency will of course also be 
related to teacher performance. So that this needs to be a concern for teachers to be able to improve their professional competence so that they can improve their performance as a professional teacher.

The role of professional educators as part of teacher performance is very much needed to realize the goals of national education, namely the intellectual life of the nation and developing human beings as a whole. The consequence of the teacher as a profession is that the professional competence of teachers must be adequate. Therefore, the development of professional competence needs to be implemented based on the Regulation of the State Minister for Empowerment of State Apparatus and Bureaucratic Reform Number 16 of 2009 concerning teacher functional positions and credit scores. In principle, the professional competence of teachers is an absolute requirement for achieving good teacher performance.

Teacher competence is a set of mastery abilities that must be present in teachers in order to realize their performance appropriately and effectively. The success of education is largely determined by teacher performance.

A teacher must have professional competence to improve their performance. [16], professional competences include: "(1) the ability to convey or speak, (2) the ability to think / intellectually, (3) the ability to maintain interpersonal relationships, (4) the ability to develop, build networks or expand relationships. work, (5) ability to develop themselves, (6) discipline.

Furthermore, [14] Competence is the knowledge, skills and abilities that a person gets to be able to do something well, including those regarding cognitive, affective and psychomotor behaviors. Based on this opinion, it can be concluded that what is meant by teacher professional competence is the ability that must be possessed by a teacher in terms of knowledge, skills and values and attitudes to do a job that is obtained through professional education and cannot be replaced by other people who do not have that profession.

The results of the study which found the influence of professional competence on teachers' performance were also supported by previous research, including research conducted by. This research is also supported by the results of research by [17] Correlation of work motivation and teacher competence with the performance of teachers of Palembang Private High Schools". The results showed that motivation, management competence and ability showed a very significant (real) effect on teacher performance, competence had a very significant effect on teacher performance.

2. The second hypothesis (Variable Partial Hypothesis X2 to Y)

Ha: $p>0$

Ho: $p=0$

H0: there was no positive and significant influence between work discipline on teachers' performance

Ha: there was a positive and significant influence between work discipline on teachers' performance

The results of the coefficient analysis obtained t-count of 3.369. Hypothesis testing criteria If the statistical $\mathrm{t}$-count $\geq \mathrm{t}$-table, then $\mathrm{Ha}$ is accepted and if the $\mathrm{t}$ statistic $<\mathrm{t}$ table, then $\mathrm{Ha}$ is rejected. To determine the $\mathrm{t}$ table is sought at $=5 \%: 2=2.5 \%$ (2-sided test) with degrees of freedom $(\mathrm{df})=\mathrm{n}-\mathrm{k}$ or $\mathrm{df}$ $=76-2=74$ ( $\mathrm{n}$ is the number of samples and $\mathrm{k}$ is the number of independent variables). With a twosided test (significant $=0.025$ ) the results were obtained for the t table of 1.98896 . Based on the explanation above, namely $\mathrm{t}$-count $=3.369$ and $\mathrm{t}$-table $=1.99254$, then $\mathrm{t}$-count $>\mathrm{t}$-table which meant that Ho was rejected and $\mathrm{Ha}$ was accepted or it was concluded that partially there was a positive and significant influence between work discipline on teachers' performance.

Work discipline in this study referred to a tool used by school principals to communicate with teachers, staff and school residents so that they were willing to change behavior and to increase awareness and willingness to obey all the rules and social norms that was appliedat SD NegeriofBanyuasin District. I.

In this study, the results of the partial test ( $t$ test) of the work discipline variable on performance found that work discipline had an influence on teachers' performance and it could be said that individual work discipline variables had a significant effect on teachers' performance with a sig value. was smaller than the probability value and $t$-count was greater than $\mathrm{t}$ - table. 
The writer also made observations on several research samples to support the research results. The results of the researcher's observations found that the work discipline of the SD Negeri teachers ofBanyuasin I district was good as seen from the fulfillment of $78 \%$ of the observational indicators that the researcher used in this study. Work discipline is one of the factors that affect performance. [8] discipline is the awareness and willingness of a person to obey all company regulations and applicable social norms. Thus discipline is an attitude to comply with and obey all organizational rules in doing work to achieve the expected goals. Discipline is related to the existence of rules or regulations. So that a disciplined teacher can be interpreted as a teacher who obeys all the rules that have been established by the organization and applicable social norms.

Good discipline reflects a person's sense of responsibility for the tasks assigned to him. With discipline, it can encourage work passion, morale, and support the realization of planned goals. High discipline will be able to build professional performance, because a good understanding of the discipline of the teacher is able to observe the rules and strategic steps in carrying out the teaching and learning process. Discipline for teachers is an integral part in carrying out their duties and obligations.

The results of this study are in line with the results of research by [9] which found a simultaneous effect of work discipline, work motivation, and school principal supervision on teacher performance by $65.4 \%$. Meanwhile, the partial effect of work discipline is $17.56 \%$ on teacher performance. With work discipline, it can improve teacher performance.

[10] through his research also proved that [9] there was a partial influence between work discipline on teacher performance by $47.47 \%$. Likewise, research by [11], [12], [13] Work discipline had a positive and significant effect on teachers' performance.

\section{Third Hypothesis (Simultaneous Hypothesis of X1 and X2 to Y Variables)}

Ha: $\rho>0$

Ho: $\rho=0$

H0: there was no positive and significant influence between professional competence and work discipline simultaneously on teachers' performance

$\mathrm{Ha}$ : there was a positive and significant influence between professional competence and work discipline simultaneously on teachers' performance

The research found that F-count was 64,221. Hypothesis testing criteria if Fcount $\geq F$ table, then Ha is accepted and vice versa if $\mathrm{F}$ statistic $<$ Ftable, then $\mathrm{Ha}$ is rejected. Based on Ftable at the real level $\alpha=$ 0.05 with $\mathrm{db}$ numerator of 2 (determined by the number of independent variables) and $\mathrm{db}$ in the denominator of 73 (determined from the number of samples minus the independent variable minus 1) or it can be determined through the Excel application program in blank cells type with the formula = FINV $(0.05,2.73)$ obtained a figure of 3.12 . Based on the explanation above, it was known that Fcount was 64,221 where Fcount $\geq$ Ftable $(64,221>3.12)$ which meant that $\mathrm{Ha}$ was accepted or it was concluded that there was a significant positive influence between professional competence and work discipline on teachers' performance.

The results of the simultaneous test of Professional Competence and Work Discipline on the Performance of State Elementary School Teachers of Banyuasin I District, it was known that the probability was much smaller than 0.05 and Fcount was greater than Ftable, so H04 was rejected and Ha4 was accepted or in other words, there was an influence of Professional Competence and Discipline. Working simultaneously on Teachers' Performance so that it can be said that the variables of Professional Competence and Work Discipline simultaneously had a significant effect on the performance of State Elementary School teachers ofBanyuasin I District. This also shows that, if Professional Competence and Work Discipline increased, it would be followed by an increase on teachers' performance and vice versa if the Professional Competence and Work Discipline decreased, it would be followed by a decrease in the performance of SD Negeri teachers ofBanyuasin I District.

The coefficient of determination test results also found that $63.8 \%$ of the teacher performance variables could be explained by the Professional Competence and Work Discipline variables. While the remaining $36.2 \%$ was explained by otherresearch variables such as compensation, working conditions and others. 
The results of the researchers' observations also found that the work performance of the SD Negeri teachers ofBanyuasin I district was good, as seen from the fulfillment of $72 \%$ of the observational indicators that the researchers used in this study. Professional teachers must have good basic skills, understand or master the material and have loyalty to their duties. Thus teachers are required to have competence. The competence that must be possessed by a teacher is professional competence, this competence emphasizes sufficient knowledge and interviews about the content of the subject so that it is absolutely necessary to create a good learning process so that the performance shown by the teacher is also better.

Professional competence is consistently one of the factors that affect teacher performance and the most important part of the quality of education. To improve the quality of education, both individually and in groups, teachers are expected to have good work performance in carrying out their duties at school. Sudarsono (2008: 147) stated that performance is the result achieved by a person according to the size applicable to the work concerned, meaning that if a person's behavior provides work results that are in accordance with the standards or criteria standardized by the organization, then the performance is classified as good and otherwise it means bad performance, or in other words, standard setting is needed to determine whether the employee's performance is in accordance with the expected target, as well as seeing the amount of deviation by comparing the actual work results with the expected results.

\section{Conclusions}

The following findings are derived based on the discussion of the study results: (1) there was a significant influence between principal leadership on teachers' performance; (2) there was a significant influence between compensation on teachers' performance; (3) there was a significant influence between principal leadership and compensation on teachers performance.(4)There was significant interaction effect of collaborative writing strategy with google docs and motivation towards eight grade students' writing ability on descriptive text at SMPN 12 Palembang.

\section{References}

Sardiman. A.M. 2011.Interaksi dan Motivasi Belajar Mengajar. Jakarta: Rajawali Press. Sinambela, Lijan Poltak. 2012. Kinerja Pegawai. Graha Ilmu: Yogyakarta

Sutermeister 1976. People and Productivity, USA.McGraw-Hill,Inc.

Gibson. et. al., 1995.Preproject planning process for capital facilities, Journal of Construction Engineeringand Management, ASCE, 121 (3), 312-318

Hamalik, O. 2008. KurikulumdanPembelajaran. Jakarta: BumiAksara.

Sopandi, A. 2019. Pengaruh Kompetensi Profesional dan Kompetensi Kepribadian Terhadap Kinerja Guru. Scientific Journal of Reflection: Economic, Accounting, Management and Business, 2(2), 121130.

Patarai, I., Mustari, M., \&Azis, M. 2018. Motivasi Mengajar, Kompetensi Profesional dan Tingkat Pendidikan terhadap Kinerja Guru. JurnalMirai Management, 3(2), 120-133

Widiastuti. 2013. Pengaruh Kompetensi Profesional Dan Motivasi Kerja Terhadap Kinerja Guru Di SMK TRIATMA JAYA Singaraja Tahun Ajaran 2012/2013. Jurnal Pendidikan Ekonomi Undiksha, 3(1).

Hasibuan, Malayu S.P. 2011. Manajemen Sumber Daya Manusia. PT BumiAskara: Jakarta.

Wahyudi, A., Thomas, P., \&Setiyani, R. 2012. Pengaruh Disiplin Kerja, Motivasi Kerja, dan Supervisi Kepala Sekolah terhadap Kinerja Guru. Economic Education Analysis Journal, 1(2), 1-8.

Masruroh, U. 2012. Pengaruh Kompensasi dan Disiplin Kerjaterhadap Kinerja Guru Ekonomi SMA Negeri Brebes. Economic Education Analysis Journal, 1(2).

Nugraheni, A. S., \&Rahmayanti, R. 2016. PengaruhDisiplinKerjaTerhadapKinerja Guru di MI Al Islam Tempeldan MI Al IhsanMedari. JurnalPendidikan Madrasah, 1(2), 277-293.

Ngiode, S. 2016. Pengaruh Kepemimpinan Kepala Sekolah, MotivasiKerja dan Disiplin Kerja terhadap Kinerja Guru MTs. N BatudaaKabupaten. Tadbir:Jurnal Manajemen Pendidikan Islam, 4(2), 127-137.

Turangan, J. K. 2017. PengaruhKompetensi, Disiplin Kerja Dan Profesionalisme Terhadap Kinerja Guru Di SMA Negeri 1 Manado. Jurnal EMBA: Jurnal Riset Ekonomi, Manajemen, Bisnisdan Akuntansi, 5(2).

Wahyudi, B. 2012.Manajemen Sumber Daya Manusia. Sulita, Bandung.

Mulyasa, 2004.Menjadi Guru Profesional, Bandung : PT RemajaRosdakarya

Asmara, UH. 2014. Profesi Kependidikan. Pontianak: Fahruna Bahagia Press. 
Hamid 2011,dengan judul "Korelasimotivasi kerja dan kompetensi guru dengan kinerja guru Sekolah Menengah Atas Swasta Palembang. 